\section{NAS PRATELEIRAS}
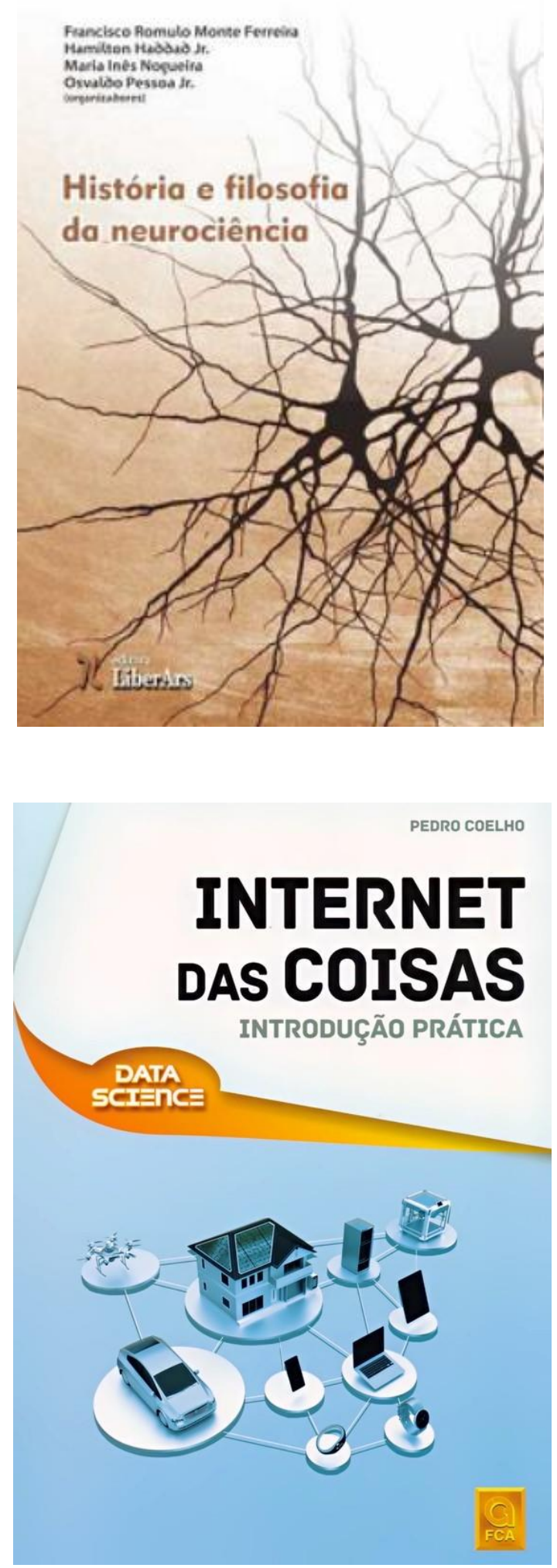

Pesquisa clínica de medicamentos no Brasil: a disposição sobre o próprio corpo

Thamires Pandolfi Cappello

ISBN: $\mathbf{9 7 8 8 5 9 4 5 9 1 3 5 7}$

Editora: LiberArs

Ano de Edição: 2017 (1 $1^{\text {a Edição) }}$

A pesquisa clínica de medicamentos, que envolve questões das mais complexas, como a experimentação com seres humanos, o próprio direito à vida e à saúde, a dignidade da pessoa humana, o desenvolvimento científico, a integridade física e a disposição sobre o próprio corpo, não tem sido explorada de forma mais ampla pelo Direito e, muito menos, pelo Direito Constitucional.

E o livro "Pesquisa clínica de medicamentos no Brasil: A disposição sobre o próprio corpo", escrito pela jovem e competente advogada e pesquisadora Thamires Pandolfi Cappello, busca romper com is so.

Fruto de sua excelente dissertação de mestrado, defendida na Pontifícia Universidade Católica de São Paulo (PUC-SP), o trabalho, que agora chega ao grande público, tem o mérito de explorar um tema tão complexo de maneira profunda e ao mesmo tempo acessível.

A autora, com uma visão que alia consis tência teórica e análises práticas, nos brinda com uma qualificada reflexão sobre os complexos e multifacetados temas abordados. 

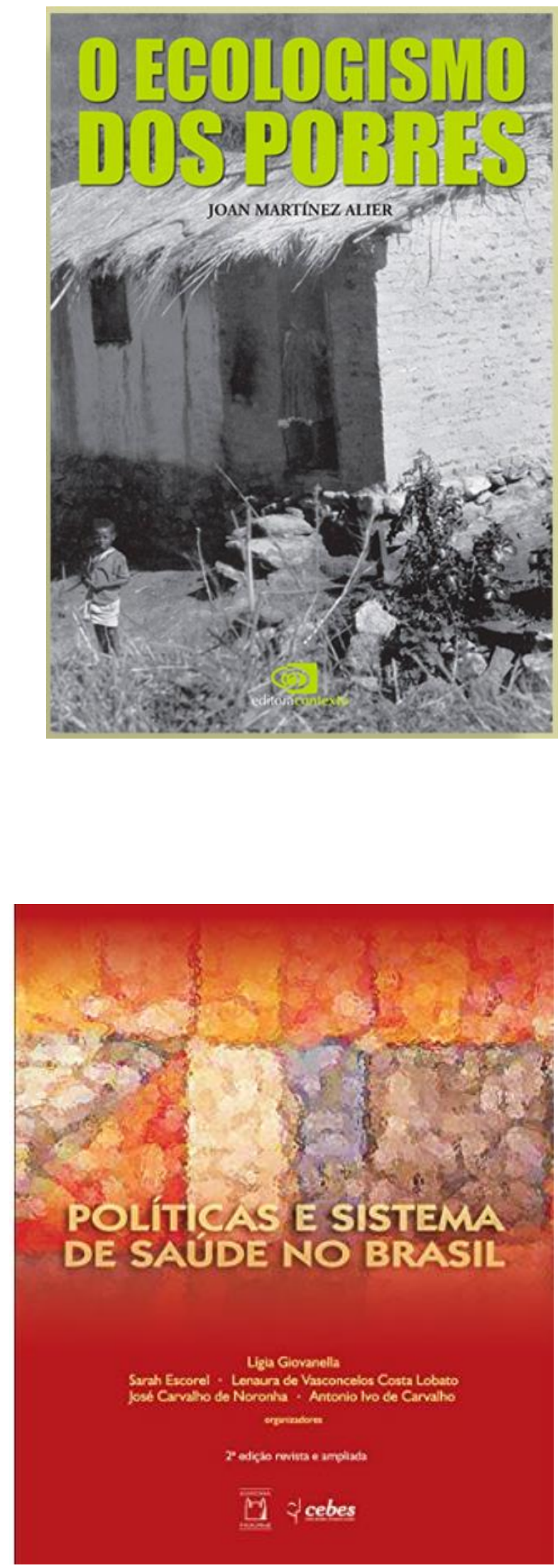

\section{O Ecologismo dos Pobres}

Joan Martínez Alier

ISBN: 978-85-72443-58-6

Editora: Contexto

Ano de Edicão: 2007 (2ª Edição)

O ecologismo dos pobres é uma importante e profunda contribuição para debates sobre meio ambiente, política e economia. Com a intenção explícita de auxiliar a estabelecer dois campos de estudos emergentes - ecologia política e economia ecológica -, o autor investiga as relações entre as duas áreas. Além disso, traça um panorama do aumento das tensões pelo acesso a recursos naturais e da relação entre progresso econômico e uso do meio ambiente. Livro imperdível para ambientalistas, geógrafos, técnicos, pesquisadores, estudantes e profissionais da economia ecológica e para todos aqueles que se interessam pelos conflitos ambientais.

\section{Políticas e sistema de saúde no Brasil Lígia Giovanella , Sarah Escorel, Lenaura de Vasconcelos Costa Lobato ISBN: 978-85-7541-417-0}

Editora: Fiocruz/Cebes Ano de Edição: 2017 (2 $2^{\mathrm{a}}$ Edição)

Como desconhecer o que é a política de saúde, o que é o Sistema Único de Saúde (SUS), os determinantes sociais, as condições de saúde e as desigualdades do acesso no Brasil? Esta obra consolida o conhecimento crítico sobre o sistema de saúde brasileiro produzido ao longo dos últimos trinta anos. Conhecimento militante na defesa do direito universal à saúde e do acesso aos serviços de um sistema nacional de saúde de qualidade para todos e de políticas de saúde que promovam a redução das desigualdades sociais. Um livro didático e de referência que inclui os eixos de análise individual/coletivo, clínico/epidemiológico e público/privado, além de congregar autores com experiência na gestão de serviços e do próprio sistema, nos três níveis da federação. A construção do SUS há muito deixou de ser obra exclusiva de intelectuais capazes de ler em língua estrangeira. Temos 'construtores' que lêem na realidade concreta dos serviços e da gestão, e que participam ativamente do complexo processo de construção cotidiana da saúde. 